\title{
Implementation of Problem-Based Learning Model on Social Science Subject in Primary School Based on 2013 Curriculum at Fifth Grade Students in Madura-East Java
}

\author{
Yemima Natalia \\ Universitas Trunojoyo Madura \\ Bangkalan, Indonesia
}

\author{
Priyono Tri Febrianto \\ Universitas Trunojoyo Madura \\ Bangkalan, Indonesia \\ priyono.febrianto@trunojoyo.ac.id
}

\begin{abstract}
The purpose of this study is to determine the learning implementation conducted by the teacher using Problem Based Learning Strategy relate to the social subject based on 2013 curriculum. The study applies descriptive qualitative for research design. Data collecting is conducted by using interviews, observation, and documentation. Data validity check is conducted through data triangulation section. Data analysis starts with data reduction, data display, and conclusion. Based on the result of study, it can be concluded that: (1) Problem Based Learning Strategy Implementation in social learning for primary education based on 2013 curriculum is considered very good to be implemented, (2) The fifth-grader homeroom teacher in SDN Pejagan 1 Bangkalan has already comprehended the implementation of Problem Based Learning Strategy.
\end{abstract}

Keywords: Problem Based Learning Strategy; Social Subject; 2013 Curriculum

\section{INTRODUCTION}

The strategy taken by a football coach on the field needs to be precise after apprehending all of the potential performances equipped by his team for the sake of gamewinning. In selecting a strategy, a football coach urges to decide whether applying an attack strategy of 2-3-5 or executing a 5-3-2 defense strategy [1]. Furthermore, the coach can also engage another defense strategy such as the 4-4-2 strategy, or assign the 2-4-4 attack strategy. The decision is taken based on the team's condition and the performance of the opponent team. Based on that illustration, the strategy is implemented to successfully achieve the goal.

According to [2], learning strategy covers several matters, such as "learning the purpose, lesson material, learning activities (methods or techniques), learning media, classroom management, and assessment". Based on the information aforementioned by Suprihatiningrum, learning strategy requires a clear learning purpose, the availability of lesson material to be discussed, and learning activities supported by learning methods and techniques before it is implemented.
According to Arends (in [2]), Problem Based Learning Strategy (PBL) has several characteristics as mentioned here:

- PBL records factual life situation that brings up various questions and problems. Thus the learners are urged to form complex answers as the possible solutions.

- By administering factual problems, PBL not only focuses on a particular subject but also designs the interdisciplinary functions that enable the learners to provide the solutions reviewed by other subjects.

- PBL requires the learners to conduct a factual investigation in order to provide factual solutions for factual problems. Furthermore, the learners must be able to analyze and define the problems, to develop a hypothesis, to establish prediction, collect and analyze information, and to conduct an experiment (if required, create inference and form conclusion).

- PBL urges the learners to produce particular handed-in product or presentation that explain or represent their established solutions. In another word, the learners are trained to create and to expose their products.

- PBL habituates the learners to collaborate either in pairs or in small groups. Collaboration is an activity that motivates them to elaborate their social and reasoning skills.

Refference [3] suggests Problem Based Learning Strategy approaches as presented in Table I.

Refference [3] asserts the role of teachers as follows:

- A teacher must be able to facilitate the students with a conducive learning environment so that each student not only obtains the opportunity to grasp various information but also accomplishes complete data.

- A teacher may establish the opportunities for students to express their opinions, also facilitate their information or facts finding with respectable sources.

- A teacher is obliged to assist the students obtaining as much as information through diverse sources. 
- A teacher must support the students to perform the learning process confidently, to determine critically whether the information they have received is right or wrong, good or bad.

- A teacher demonstrates the enthusiasm, care, and responsibilities to solve various problems.

TABLE I. APPROACHES TO PROBLEM BASEd LEARNING STRATEGY IMPLEMENTATION

\begin{tabular}{|l|l|l|}
\hline \multicolumn{2}{|c|}{ Approaches } & \multicolumn{1}{|c|}{ Activities of Teacher and Learner } \\
\hline 1. & $\begin{array}{l}\text { Observe and } \\
\text { orientate the } \\
\text { problem }\end{array}$ & $\begin{array}{l}\text { Learner conducts an observation on particular } \\
\text { phenomenon that relates to the Basic } \\
\text { Competency }\end{array}$ \\
\hline 2. & $\begin{array}{l}\text { Issue questions } \\
\text { and problems }\end{array}$ & $\begin{array}{l}\text { Learner forms a problem related to the observed } \\
\text { phenomenon. The problem is constructed in } \\
\text { disputable questions }\end{array}$ \\
\hline 3. & $\begin{array}{l}\text { Collect and } \\
\text { analyze the data }\end{array}$ & $\begin{array}{l}\text { Learner collects the information (data) on how to } \\
\text { form the problem solution by reading various } \\
\text { reference, conducting section observation, } \\
\text { administering interviews, and many other } \\
\text { activities either individually or collectively. }\end{array}$ \\
\hline 4. & $\begin{array}{l}\text { Associate and } \\
\text { form the } \\
\text { solution }\end{array}$ & $\begin{array}{l}\text { Learner analyzes the data and forms the solution } \\
\text { of the problem issued }\end{array}$ \\
\hline 5. & $\begin{array}{l}\text { Communicate } \\
\text { Learner presents the solution to the problem. The } \\
\text { teacher helps learner conduct evaluation on the } \\
\text { problem-solving process }\end{array}$ \\
\hline
\end{tabular}

Based on the preliminary information, Problem Based Learning Strategy has been implemented in SDN Pejagan 1. Unfortunately, during its implementation, an unsupportive situation emerges, such as how a hyperactive student annoys the other students in the class and even how a student brings up a sensitive family matter to the class. Nevertheless, the researcher manages to obtain other factual information illustrating the fact that Problem Based Learning Strategy has never been implemented in fifth grade. Furthermore, it is indicated that the teachers are not fully equipped with the basic knowledge of learning strategy and its types.

Based on the aforementioned background, it can be asserted that the research problem is the implementation of Problem Based Learning Strategy used by fifth-grade teachers in theme three sub-theme three learning six of Social learning based on 2013 curriculum. Corresponded with the problem establishment, the research purposes to identify the implementation of Problem Based Learning Strategy used by fifth-grader teachers in theme three sub-theme three learning six of Social learning based on 2013 curriculum.

\section{METHODS}

This research is a qualitative-descriptive research conducted in SDN Pejagan 1, Bangkalan with the population of all teachers in SDN Pejagan 1, Bangkalan. Furthermore, the research uses purposive sampling technique with a sample of a fifth-grade homeroom teacher at SDN Pejagan 1, Bangkalan.

The data collection approach in this qualitative research involves: (1) observation technique that is used to monitor the Problem Based Learning Strategy learning activity; (2) indepth interview technique which is applied to seek how
Problem Based Learning Strategy is implemented on 2013 curriculum at school; (3) documentation technique that is taken to record and to collect data from previous events.

The data analysis conducted in this research uses (1) data reduction which summarizes and selects primary data related to the topic; (2) data display which provides easier comprehension; (3) conclusion drawing that has the possibility to solve the problem.

After observation, in-depth interview and documentation techniques are completed to collect the data, therefore the verification is as follows:

\section{RESUlT AND DisSCUSSION}

Based on the result of the data collecting, it is asserted that learning methods, techniques, and media can assist and facilitate teachers in implementing Problem Based Learning Strategy to achieve the designated learning purposes.

\section{A. Learning Process of Problem Based Learning Strategy Research Activity}

Based on the result of this research, the fifth-grader homeroom teacher has successfully taught the class using Problem Based Learning Strategy. Furthermore, the assessment of the learning result on theme three is provenly better and higher than the other themes, such as theme one, theme two and theme four.

Due to the improvement of the learning result on theme three with the implementation of Problem Based Learning Strategy, it can be concluded that Problem Based Learning Strategy is applicable to learning activities. Additionally, the elevated students' learning result is also sustained by learning approaches conducted by the teacher. Through the medium of the approaches conducted by the fifth-grader homeroom teacher, the students are motivated to think critically and solve their problems independently. Thus, the students now have better understandings towards the lesson presented by their teacher.

\section{B. Implementation of Problem Based Learning Strategy}

Based on the data collecting in this research, the fifthgrader homeroom teacher is able to implement the Problem Based Learning Strategy towards the learning process. The implementation of Problem Based Learning Strategy conducted by Amirusi, the fifth-grader homeroom teacher at SDN Pejagan 1, Bangkalan matches with the criteria presented in Problem Based Learning Strategy.

The criteria of Problem Based Learning Strategy are (1) Problem Based Learning Strategy definition, (2) Problem Based Learning Strategy attributes, (3) Problem Based Learning Strategy characteristic, (4) learning with Problem Based Learning Strategy approaches, (5) the role of the teacher in Problem Based Learning Strategy.

Principally, the fifth-grader homeroom teacher has acknowledged and comprehended the definition of Problem Based Learning Strategy which focuses on the problemsolving. During the learning session, the fifth-grader 
homeroom teacher not only asks the students to listen, to note and to memorize the lesson but also addresses on student activeness.

The students are requested to solve their own problems, by examining the illustrations on the student book, collecting the data or information by themselves. This proven that the students not only take notes, listen, memorize but also actively take part in the learning process.

The $5^{\text {th }}$-grader homeroom teacher provides factual live phenomenon so that it assists the students to comprehend the lesson easier. Thus the teacher also queries questions that demand respectable solutions.

The learning process also conducted by the $5^{\text {th }}$-grader homeroom teacher focuses on interdisciplinary functions that match with 2013 curriculum applied in SDN Pejagan 1. The problem that is presented in a particular subject also relates to another subject, such as lesson in Social can be related to the lesson found in Civic Education.

The lesson presented on this subject has factual phenomenon or events happen in the real life, therefore it requires factual solutions as well. For example, students are confronted with the topic on how the society's role towards their environment. In this task, the students are requested to gather related information hence analyze it.

During the lesson, students are expected to create products or school work such as a scrapbook. When the students finish the tasks they are asked to present the tasks in front of the class. In this type of learning, students are divided into several groups. All students are required to cooperate well to solve the problems.

Based on the evidence shown, the $5^{\text {th }}$-grader homeroom teacher demonstrates the comprehension of the Problem Based Learning Strategy including its characteristic. The activities conducted by the teacher match with the characteristic of Problem Based Learning Strategy.

The $5^{\text {th }}$-grader homeroom teacher starts the approaches by asking the students to observe an illustration that shows several behavior patterns in society that either can be taken as a model after or need to be avoided. For example, the illustration shows the picture of someone who is littering, someone who puts the trash in the bin and someone who is quarreling. By completing the observation, the students are able to identify the problems.

Problems will emerge questions. Furthermore, the teacher continues by providing guidance and driving the students to gather information. Information collecting is simply undertaken by observing several events either in the real environment or on the internet. In this learning process, the students are divided into working groups.

Once the information is collected, the students will analyze it. Moreover, a result will be presented in front of the class. Each group presenting the solution is represented by one participant of the group. Each group will be given a time of 10 minutes to complete the presentation. During the presentation, the teacher has a role to facilitate the students so that they have equal perceptions. Eventually, by the end of the session, the teacher comes up with a lesson conclusion.
The approaches undertaken by the teacher have a match with the approaches of Problem Based Learning Strategy. This proves that the $5^{\text {th }}$-grader homeroom teacher has grasped the respectable approaches to implementing Problem Based Learning Strategy.

During the implementation of Problem Based Learning Strategy, the $5^{\text {th }}$-grader homeroom teacher always provides a conducive learning environment for the students. They are allowed to reveal their opinions. Furthermore, the $5^{\text {th }}$-grade homeroom teacher also respects the opinions given by the students and never plainly shows the disapproval for incorrect or inappropriate answers. The students are fully assisted in searching for information from any sources as well as from the books and the internet. Moreover, the students are encouraged to perform independently and critically. The $5^{\text {th }}$-grade homeroom teacher not only demonstrates the concern towards the problems but also soon together with the students puts the best effort to find the solutions.

Based on the accomplishment above, it is proven that the $5^{\text {th }}$-grade homeroom teacher has satisfactorily completed the role of a teacher. The motivation, facilities, and care is given by the $5^{\text {th }}$-grade homeroom teacher have encouraged the students to be skillful in problem-solving.

\section{C. $\quad$ Supporting Factors of Problem Based Learning Strategy Implementation}

Based on the data collecting during Problem Based Learning Strategy implementation, there are several supporting factors: (1) the 2013 curriculum has an important part on the implementation, since it enables thematic and interdisciplinary learning, (2) the Social subject has remarkably role in accomplishing the Problem Based Learning Strategy implementation since the lessons relate to factual phenomenon in the society, (3) the problems presented to the students are real problems taken from the factual phenomenon, (4) Problem Based Learning Strategy enables the students to expose their opinions deliberately so that they are able to seek their own solutions, (5) the learning activities are created based on the problem solving that relates to factual life and problems, therefore they can assist the students understanding the lesson, (6) the Problem Based Learning Strategy enables the students to think critically, thus they will focus on the lesson.

The supporting factors of the Problem Based Learning Strategy implementation accommodate the student's theme three activities and learning result into a better level compared to other themes.

\section{CONCLUSION}

Based on the research result, it can be concluded that: (1) implementation of the Problem Based Learning Strategy in Social subject at Primary Education level based on 2013 curriculum is appropriate to be undertaken since the students are able to form problem solving, (2) the $5^{\text {th }}$ grade homeroom teacher at SDN Pejagan 1, Bangkalan, Amirusi, S.P.d has understood the implementation of the Problem Based Learning 
Strategy towards the learning process in that the learning activities have match with the attributes, characteristics, and approaches of the Problem Based Learning Strategy implementation. In regard to the aforementioned conclusion, there are favourable suggestions as follows: (1) the teacher needs to prepare a suitable learning strategy which correspond to the lesson, (2) the lesson must be presented in interesting approaches, such as through story or song, (3) the students need to be motivated or praised so that they can perform well during the lesson.

\section{REFERENCES}

[1] Sanjaya, Wina. 2013. Strategi Pembelajaran Berorientasi Standar Proses Pendidikan. Cet. Kesepuluh. Jakarta: Kencana.

[2] Suprihatiningrum, Jamil. 2014. Strategi Pembelajaran Teori \& Aplikasi. Cet. Kedua. Jogjakarta: Ar-ruzz Media.

[3] Kosasih. 2014. Strategi Belajar dan Pembelajaran Implementasi Kurikulum 2013. Cet. Pertama. Bandung: Yrama Widya. 